\title{
The Effect of Accounting Disclosure about Sustainability Reports on the Ability of Banks to Going Concern - Case Study of Arab Bank
}

Dr. Ammar Daher Bashatweh (Corresponding author)

ORCID ID: https://orcid.org/0000-0002-2628-2099

Tel: 962-797-942-007Ｅ-mail: bashatwahammar@yahoo.com

Dr. Salam Nawaf AlMomani

Faculty of Administrative and Finance, Aqaba University of Technology, Aqaba, Jordan

Tel: 962-797-011-538Ｅ-mail: almoumany@yahoo.com

Received: April 7, 2020 Accepted: April 24, 2020 Published: May 9, 2020

doi:10.5296/ber.v10i2.17006ＵRL: https://doi.org/10.5296/ber.v10i2.17006

\begin{abstract}
The main objective of the study was to identify the effect of accounting disclosure of sustainability reports on Going Concern in the Arab Bank. To achieve the objective of the study, the content of the sustainability reports issued by Arab Bank were analyzed to identify the disclosure level for the economic, environmental and social dimensions in accordance to the (GRI,2014) initiative indicators. Furthermore, the Going Concern ability of the bank was measured using a set of financial indicators selected based on the results reported in previous literature addressing Continuity in commercial banks. Data used in the current study was taken from the sustainability reports and the annual statements issued by The Arab Bank (2010-2014). The study concluded that there is a significant effect of the disclosure of the dimensions of all the sustainability reporting on the return on assets and the return on equity). The study recommended the need for Arab Bank to disclose the dimensions of sustainability dimension in accordance to the International disclosure Initiative (GRI, 2014).There is also a need for more disclosure of the accounting activities in annual statements to provide a clearer picture for the sustainability accounting statements and annual statements which reflect the Arab Bank concern with respect to sustain the community resources and its ability to Concern Going.
\end{abstract}

Keywords: Sustainability Reports, Accounting disclosure, Going Concern, Arab Bank 


\section{Introduction}

The financial statements are considered the essential and main tool for beneficiaries to make decisions and with the rapid change in this current era, such statements do not sufficiently express the various dimensions of the value of the establishment. Accordingly, there was a need for disclosing the non-financial information so it would include the sustainability, which was not covered by the financial lists and reports. Thus the importance of the social and environmental disclosure appeared and then evolved to the disclosure of the sustainable development throughout the social, economic and environmental dimensions. We can further say that the sustainability accounting depends on expanding the financial accounting framework to meet the new variables including the rule of service, which focuses on new factors for the success of the establishment. Furthermore, there was a need to issue special reports called the sustainability reports which has emerged as a response to the growing global impact on the impact of the environmental, social and economic dimensions on the organizations' activities. Due to the fact that the traditional accounting reports do not adequately provide information about the three dimensions of sustainability (Yongvanich and Guthrie, 2006). The sustainability accounting in the current era represents one of the most important issues for the establishments that want to have a future since the social, environmental and economic performance might be among the factors indicating that the establishment is moving towards continuity and survival, thus achieving the desired success for all parties (Epstein \& Roy, 2001).

By establishing the concept of sustainability as one of the important concepts, the Arab Bank, since 2010, started to pay attention to the concept of sustainability with its three dimensions through depending on the Global Reporting Initiative (GRI). The Bank has issued its first sustainability report as a summary of the environmental, social and economic performance being the first bank in Jordan to issue a sustainability report. The role of sustainability reports is important in the success of the organizations to achieve competitive advantage (Bashatweh,2018). It is therefore expected that sustainability reoprts discloure to be expected improve going concern. This study was conducted to identify the effect Accounting Disclosure about sustainability reports (Social, Environmental, Economic) dimensions on going concern of Arab Bank. Thus the problem of the study can thus be expressed in the following questions:

1. Is There an effect for (environmental, social, economic) dimension Disclosure on return on assets?

2. Is There an effect for (environmental, social, economic) dimension Disclosure on return on Equity?

3. Is There an effect for (environmental, social, economic) dimension Disclosure on Total loans to Total Assets?

4. Is There an effect for (environmental, social, economic) dimension Disclosure on EBIT to Total Assets?

5. Is There an effect for (environmental, social, economic) dimension Disclosure on Working capital to Total Assets? 


\section{Macrothink}

6. Is There an effect for (environmental, social, economic) dimension Disclosure on Operating cash flow to Total Assets?

7. Is There an effect for (environmental, social, economic) dimension Disclosure on Non-Performing loans to Total Loans?

8. Is There an effect for (environmental, social, economic) dimension Disclosure on Gap between gross and net income?

\section{Study Objectives and Importance}

The main objective of this study is to investigate the effect Accounting Disclosure about sustainability reports (Social, Environmental, Economic) dimensions on going concern indicators of Arab Bank. As for the importance of this study is that it shows to managers, investors and other decision makers that there is a relationship between sustainability reports disclosure and going concern, so that based on these results they can take more informed decisions about issuing sustainability reports or not. Thus, the present study will be useful to banks' managers and stakeholders, as well as contributing to the literature and future studies.

\section{Literature Review}

\subsection{Sustainability Reports}

Sustainability reports is among the public reports provided to stakeholders for the purposes of illustrating environmental, economic and social dimensions, and the contributions of the organization to these dimensions (Oliver's, 2011). The concept of banking sustainability reports refers the report issued by businesses and which includes the social, economic and environmental dimensions related to its activities (GRI, 2014). Sustainability reports includes three Dimensions:

1. Social Dimension: the impacts of the organization on social systems in which it operates: employment, appropriate work conditions, human rights, community and responsibility of the product (GRI, 2014).

2. Economic Dimension: which is concerned with the impacts of the organization on the economic conditions of the stakeholders and the economic conditions at the global, national and local levels (GRI, 2014).

3. Environmental Dimension: which is concerned with the impact of the organization on the biological living and non-living systems which include the earth, air and the biosphere (GRI, 2014).

Based on the Global Reporting Initiative (GRI, 2014) table (1) shows explains the dimension and principles of sustainability reports: 


\section{$\triangle$ Macrothink}

Table 1.

\begin{tabular}{|l|l|l|}
\hline$\#$ & Details & Explain \\
\hline Dimension & 1. Economic & $\begin{array}{l}\text { provides information about such things as: Economic Performance, } \\
\text { Market Presence, Indirect Economic impacts, Anti-corruption }\end{array}$ \\
\cline { 2 - 3 } & 2. Environmental & $\begin{array}{l}\text { provides information about such things as: Materials, Water\& } \\
\text { Effluents, Energy, Environmental Compliance }\end{array}$ \\
\cline { 2 - 4 } & 3. Social & $\begin{array}{l}\text { provides information about such things as: Customer health \& safety, } \\
\text { child labor, Marketing \& Labeling, Public Policy. }\end{array}$ \\
\hline Principles & 1. Report Content & Materiality, sustainability context, completeness, stakeholder inclusiveness \\
\hline & 2. Report Quality & Balance, Accuracy, Timeliness, Comparability clarity, reliability \\
\hline
\end{tabular}

The sustainability reports are a means of communication between the establishment and the stakeholders, so the value of the establishment is affected by its relationship with the stakeholders and through the ability of the establishment to communicate the effects of all its activities to the stakeholders. The commitment and disclosure of the economic, environmental and social activities can be a path for the establishment to achieve a long-term success, safety and growth (KPMG, 2008)

\subsection{Going Concern (Continuity):}

The International Accounting Standards Committee (IASC) has issued the Financial Statement Standard No. 1, which is based on preparing the financial statements on the basis that the organization continues to work for the foreseeable term, and that the financial statements are prepared for general objectives on the basis that the organization continues unless the management intends to stop its operations since it has no practical choice. The researchers believe that imposing continuity in accounting means that the enterprise continues its operations and that the preparation of its financial statements is based on continuity unless there are financial and non-financial indicators indicating the enterprise's inability of continuity. According to the Continuity Enforcement Audit st. no 570, the International Federation of Accountants (2010) identified a set of indicators that help to detect uncertainties on the enterprise ability of continuity. Table (2) shows the most important indicators that can be inferred when assessing continuity 
Table 2. Events or conditions that, may cast significant doubt about on the entity's ability to continue as a going concern assumption

\begin{tabular}{|l|l|}
\hline Financial & Net liability or net current liability position \\
\hline & Adverse key financial ratios. \\
\hline & Indications of withdrawal of financial support by creditors. \\
\hline & Arrears or discontinuance of dividends \\
\hline & Chability to pay creditors on due dates \\
\hline Operating & Loss of a major market, key customer(s), franchise, license, or principal supplier(s) \\
\hline & Loss of key management without replacement \\
\hline & Shortages of important supplies \\
\hline Others & Management intentions to liquidate the entity or to cease operations \\
\hline & Non-compliance with capital or other statutory requirements. \\
\hline & Changes in law or regulation or government policy expected to adversely affect the entity \\
\hline & $\begin{array}{l}\text { Pending legal or regulatory proceedings against the entity that may, if successful, } \\
\text { result in claims that the entity is unlikely to be able to satisfy }\end{array}$ \\
\hline
\end{tabular}

\subsection{Sustainability Reports and Organization Performance}

The collapse of the financial market in 1929 revealed the importance of the availability of information and the risks that may surround the financial markets due to the lack of information about companies (Allen, 2006). It also drew attention to the role of investors and the members of the community by obliging companies to expand disclosures on their financial resource in light of some rules set by regulators (Thel, 1990). Half a century later, the optional disclosure was applied in the context of regulating the corporate working environment (Case, 2005). Decades later, an idea expanded stating that the optional disclosure on the social, environmental and economic impacts would protect the company against the negative external factors. Accordingly, the FASB on 2000 defined the optional disclosure as the information not clearly required in the accounting rules or the accounting standards. Despite the increased level of disclosure, there is no conclusive evidence on the relationship between the companies' commitment to the disclosure of the environmental and social dimensions on the one hand, and the good financial performance on the other (Pfund, 2003). However, some studies have shown a correlation between the increased level of disclosure of the non-financial aspects of the company and its profitability (Robertson \& Nicholson, 1996). Furthermore, the fluctuations in the stock prices declined when the level of the disclosure increased in the 1960s (Allen, 2004). Allen's study (2006), which involved 800 companies committed to the GRI (2006) initiative that are distributed across more than 40 countries, indicated that there was a medium positive relationship between the level of compliance with the overall framework of the initiative, the stability of the company's share prices, the high operating profits and the increased revenues. Other studies followed showing a relationship between the disclosure of the environmental and social aspects and the 
financial performance of enterprises, and that there was a positive impact of the disclosure of the social aspects on the financial performance of enterprises (Darmawan, 2011). This indicates a relationship between the results of the business of companies and the society in which they operate, where the members of the community view companies as a source of developing the peoples' standard of living and the development of society at large. Therefore, the satisfaction of society reflects on the reputation and performance of companies and their ability to continue and grow. This was referred as social power in the literature (Ongundele \& Olajide, 2012). The researchers noted that the information optionally disclosed is divided into three types: qualitative information, information on the company's operational processes and information on the future prospects (Epstein and Birchard, 1999). The researchers adopted various theories in analyzing the reasons for the difference in the level of the optional disclosure, including:

1. Agency Theory: it believes that separating the owners from the management of the company makes the disclosure an important means of communication between the management and the external investors, which alleviates the agency's problem. According to this theory, the mangers' commitment to increasing the level of disclosures indicates that the management performance corresponds to investors' interests (Leftwich, et al., 1981).

2. Discrimination Theory: It indicates that the company seeks to distinguish itself and increase its market value and avoids its valuation with matters less than it deserves through increasing the optional disclosure in the financial reports. The insufficient disclosure is explained as bad news which the company is trying to hide. (Zimmerman; and Watts, 1986)., (Ghazali, 2008).

3. legitimacy theory: According to legitimacy theory, a company needs to have legitimacy in the sense of a social license to operate to access the necessary resources to successfully conduct business. Legitimacy theory suggests that no organization has an inherent right to exist but that any business operation is subject to a greater acceptance granted by society. Such legitimacy, however, is potentially threatened if society perceives that a company is not operating in an acceptable way. Accordingly, legitimation strategies aim at securing legitimacy as a valuable resource itself. Considered The preparing sustainability reports as a social contract between the organization, the environment and the society in which it operates gives it the legal legitimacy to own and use natural resources and to exploit human resources, taking into account local laws and regulations. (Bashatweh,2018)

\subsection{Pervious Study}

(Andania,\& Yadnya, 2020) The purpose of this paper investigate the effect of sustainability report disclosure on the financial performance of banks listed in Indonesia Stock Exchange (IDX) during the period of 2013-2016. The study the dimensions of sustainability report disclosure were measured through indicators that have been developed which are in accordance with Global Reporting Initiative (GRI) G4 Index and the financial performance measured through Return on Assets (ROA). The study results revealed that the disclosure of the economic and social dimensions had a statistically significant effect on ROA while the environmental dimensions did not affect the ROA. This means that the banks listed in 
Indonesia Stock Exchange (IDX) give more priority to the economic and social dimension disclosure, than to the environmental dimensions

(Bodhanwala,\& Bodhanwala, 2018) The purpose of this paper is to study whether corporate sustainability impacts profitability performance in India as the study sample consisted 58 Indian firms that are consistently a part of Thomson Reuters Asset 4 ESG database. The results found the study reveals a significant positive relationship between sustainability and firm performance measures (return on invested capital, return on equity, return on assets and earnings per share). Empirical evidence suggests that firms that practice remarkable sustainable development strategies report higher profitability and have substantially low gearing level.

(Kasbuna, \& Teh, \& Ong, 2017) The purpose of this research investigates the relationship between sustainability reporting and financial performance of Malaysian Public Listed Companies as the study sample consisted 200 Public Listed Companies in Bursa Malaysia. based on the regression results suggest that economic, social and environmental sustainability reporting is positively associated with financial performance measured using Return on Assets and Return on Equity.

(Bhuyan, Lodh, \& Perera, 2017) The purpose of this paper is to study whether corporate sustainability impacts profitability performance in Bangladesh as the study sample consisted Top 200 firms (based on market capitalization) listed on the Dhaka Stock Exchange (DSE) are considered as the sample for this study for the period 2011-2014. Firm performance is measured based on three indicators including Return on Asset (ROA), Market Capitalization, and Tobin Q. A corporate social disclosure index (CSDI) including three categories (long-term, short- term and general disclosure) is constructed to measure the extent of social disclosures in annual reports. The results found that there is a significant relationship between corporate social disclosure and the following year's firm performance for every performance indicator. It is also found that long-term disclosure plays a key role in influencing the firm performance.

\section{Framework of the Study}

Independent Variables

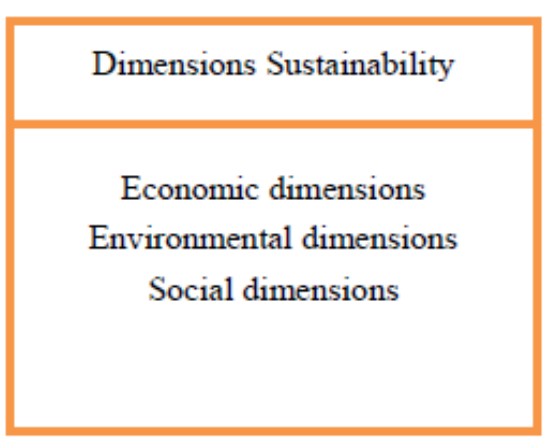

Dependent Variables

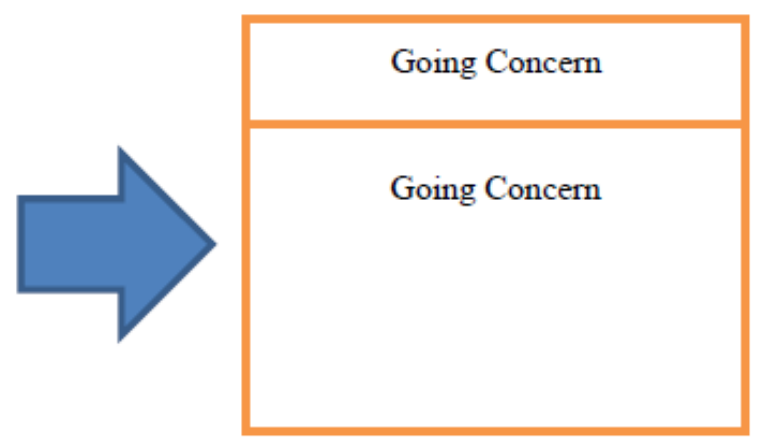

Figure 1. Study Framework / research design 


\section{Hypotheses of the Study}

Empirical Studies have a mixture of findings between sustainability reports disclosure and going concern. This study predicts a no effect of sustainability reports disclosure on going concern

HO1: There is no effect for (environmental, social, economic) dimension Disclosure on return on assets

HO2: There is no effect for (environmental, social, economic) dimension Disclosure on return on equity

HO3: There is no effect for (environmental, social, economic) dimension Disclosure on Total loans to Total Assets

HO4: There is no effect for (environmental, social, economic) dimension Disclosure on EBIT to Total Assets

HO5: There is no effect for (environmental, social, economic) dimension Disclosure on Working capital to Total Assets

HO6: There is no effect for (environmental, social, economic) dimension Disclosure on Operating cash flow to Total Assets

HO7: There is no effect for (environmental, social, economic) dimension Disclosure on Non-Performing loans to Total Loans

HO8: There is no effect for (environmental, social, economic) dimension Disclosure on Gap between gross and net income.

\section{Population and Sample}

There are 16 banks in Jordan Listed in Amman Stock Exchange which are divided into two sets of banks. The first set of banks represents the 13 commercial banks. The second set of banks represents the 3 Islamic banks. the sample of this study Arab bank. This study covers a five-year period to examine sustainability reports disclosure and going concern in Arab bank.

\section{Data Collection}

To achieve the aim of the study the descriptive and analytical approach was utilized. The study relied on two main sources for data collection: for the collection of secondary data: study utilized the previous studies, books periodicals scientific journals, and publications related to the subject of study. As for primary data, the study utilized the sustainability reports to collect the data needed for the study, for the Arab bank....

\section{Regression Model}

The study utilizes well-established model that used by previous studies The dependent variable is going concern, while the independent variable is sustainability reports Disclosure. To examine the effect sustainability reports disclosure on going concern, we use the following model: 
$\mathrm{GC}_{\mathrm{i}}=\mathrm{a} 0+\mathrm{a}_{1}$ ENVDISI $+\mathrm{a}_{1}$ ECODISI $+\mathrm{a}_{1}$ SOCDISI $+\mathrm{ei}$

Where

$\mathrm{GC}=$ going concern

ENVDISI = Environmantal Discloure

ECODISI $=$ Economic Discloure

SOCDISI $=$ Social Discloure

a1 $=$ The coefficients of variables

$\alpha=$ Constant

$\mathrm{e}=$ Random Error of variable

\section{Measurement of Variables}

Table (3) shows Measurement Independent Variable and dependent Variable:

Table 3. Measurement of variables

\begin{tabular}{|c|c|c|c|}
\hline \multicolumn{2}{|l|}{ Variables } & Measurement & Sources \\
\hline $\begin{array}{l}\text { Independent } \\
\text { Variable }\end{array}$ & $\begin{array}{l}\text { Sustainability reports } \\
\text { disclosure level based on } \\
\text { sustainability index content } \\
\text { analysis According to the } \\
\text { Global Reporting Initiative } \\
\text { (GRI) }\end{array}$ & Sustainability reports Disclosure & $\begin{array}{l}\text { (Kamal \& } \\
\text { Deegan, } \\
2013)\end{array}$ \\
\hline \multirow{8}{*}{$\begin{array}{l}\text { Dependent } \\
\text { Variables }\end{array}$} & \multirow[t]{8}{*}{ Going Concern } & Net Profit after Tax / Total Assets & \multirow{8}{*}{$\begin{array}{l}\text { (Vaziri, et al., } \\
2012) \\
\text { (Erdogan, } \\
2008)\end{array}$} \\
\hline & & Net Profit after Tax / Total Equity & \\
\hline & & Total loans / Total Assets & \\
\hline & & EBIT / Total Assets & \\
\hline & & Working capital / Total Assets & \\
\hline & & Operating cash flow / Total Assets & \\
\hline & & Non-Performing loans / Total Loans & \\
\hline & & Log Gap between gross and net income & \\
\hline
\end{tabular}

\section{Empirical Results and Discussion}

\subsection{Descriptive Statistics}

Shows the main descriptive statistics for the dependent and independent variables it shows the minimum, maximum, statistical mean, standard deviation. 
Table 4. Descriptive Statistics

\begin{tabular}{|l|l|l|l|l|}
\hline & Mean & Std. Dev. & Maximum & Minimum \\
\hline ROA & 1.062 & 0.282 & 1.411 & 0.622 \\
\hline ROE & 6.56 & 1.761 & 8.753 & 3.832 \\
\hline LNGAP & 20.159 & 0.094 & 20.296 & 20.057 \\
\hline LOANS/TA & 0.428 & 0.011 & 0.444 & 0.416 \\
\hline INTINCOME/TA & 0.022 & 0.001 & 0.0235 & 0.021 \\
\hline WC/TA & -0.368 & 0.098 & -0.233 & -0.472 \\
\hline OCF/TA & 0.19 & 0.34 & 0.8 & 0.031 \\
\hline CR & 0.92 & 0.013 & 0.11 & 0.08 \\
\hline Economic & 62.222 & 31.031 & 88.889 & 11.111 \\
\hline Environmental & 38 & 15.384 & 50 & 16.667 \\
\hline Social & 50.222 & 13.842 & 62.222 & 31.111 \\
\hline
\end{tabular}

The above table describes the continuity indicates of the Arab Bank for the period (2009-2014) that represent the post-sustainability reporting period. The standard deviation values of all the ratios show the low level of dispersion among the values, which is an indicator of the bank's financial stability regardless of the information content of each indicator. The Ratio of the Operating Cash Flow to the Total Assets (OCF/TA) is excluded since it showed a clear dispersion; however, the maximum value and the minimum value of this ratio indicate that the bank achieved positive net operating cash flows during the period. As for the liquidity index of the net working capital to the total assets (WC/TA), it indicates that the bank has suffered from a lack of liquidity during the period despite that such a lack did not affect the bank's activities and stability as understood by the rest of the ratios.

The table describes the dimensions of the sustainability reports during the study period (2009-2014), the average disclosure of the economic aspect was (62.222) and the standard deviation was (31.031\%). The highest rate of the disclosure of the economic aspect during the study period was $88.889 \%$ while the lowest percentage was $(11.111 \%)$. As for the average disclosure of the environmental aspect, it amounted to (38.000) and the standard deviation was $(15.384 \%)$ and the highest disclosure rate for the environmental aspect during the study period was 50,000) while the lowest percentage was $(16.667 \%)$. The average disclosure of the social aspect was (50.222) and the standard deviation was (13.842\%). The highest disclosure rate for the social aspect during the study period was $(62,222)$ while the lowest percentage was $(31.111 \%)$. We note that the average disclosure of the economic aspect was the highest, which may be attributed to the ease of measuring and determining the economic aspects, which may also explain the low level of the disclosure for the environmental and social aspects. In addition, many items contained in the general framework of the Global Reporting Initiative do not apply to the Jordanian environment, or they do not apply to the nature of the bank's work, which is concerned with banking issues that are apart from the environmental pollution and the harm to the surrounding community due to the operational processes as in the industrial companies, not to mention the difficulty of measuring many 


\section{Al Macrothink}

environmental and social aspects involved in the general framework.

\subsection{Multicollinearity}

This phenomenon indicates that there is a near-total linear correlation between two or more variables, which amplifies the value of the $\mathrm{R}^{2}$ selection factor and makes it larger than its actual value, so the value of the inequality inflation coefficient for each variable is calculated according to the hypothesis being tested. The results were as follows: the table (6) shows that all the values of the inflation factor of variance were greater than number 1 and less than 10 . This indicates that there was no problem of the multiple linear correlation among the study variables.

Table 6. Multiple linear correlation among the independent variables

\begin{tabular}{|l|l|l|}
\hline NO. & Variables & VIF \\
\hline $\mathbf{1}$ & Economic dimensions & 3.866 \\
\hline $\mathbf{2}$ & Environmental dimensions & 3.304 \\
\hline $\mathbf{3}$ & Social dimensions & 1.664 \\
\hline
\end{tabular}

To confirm the previous finding, Pearson's correlation coefficients among the dimensions of the independent variable were used to ensure that there was no multiple linear correlation among the independent variables of the disclosure of sustainability reporting dimensions.

The table (7) shows that the highest correlation among the independent variables is $(0.755)$ between the variables (economic aspect) and (environmental aspect) while the values of the correlation coefficient among the other independent variables were lower. This indicates there was no multiple linear correlation among the independent variables since all of them were less than (0.80), so the sample is free of the problem of the multiple high linear correlation (Gujarati \& Porter, 2004).

Table 7. Correlation among the independent variables

\begin{tabular}{|l|l|l|l|}
\hline Variables & Economic & Environmental & Social \\
\hline Economic & 1 & & \\
\hline Environmental & 0.755 & 1 & \\
\hline Social & 0.383 & 0.04 & 1 \\
\hline
\end{tabular}

\subsection{Hypotheses Testing}

Subjecting the study hypotheses to the analysis of Multiple linear regressions, the results were as follows: 
Table 8. Results of the effect for (environmental, social, economic) dimension Disclosure on going concern indicators

\begin{tabular}{|c|c|c|c|c|c|c|c|c|c|}
\hline \multicolumn{5}{|c|}{ Coefficients } & \multirow[t]{2}{*}{ Sig $F^{*}$} & \multirow[b]{2}{*}{$\mathrm{F}$} & \multirow[b]{2}{*}{$\mathrm{R} 2$} & \multirow[b]{2}{*}{$\mathrm{R}$} & \multirow{2}{*}{$\begin{array}{l}\text { dependent } \\
\text { Variables }\end{array}$} \\
\hline Sig $t^{*}$ & $\mathrm{~T}$ & Std. Error & $\beta$ & $\begin{array}{l}\text { Independent } \\
\text { Variables }\end{array}$ & & & & & \\
\hline 0.006 & 107.771 & 0.019 & 1.996 & Economic & \multirow[t]{3}{*}{0.009} & \multirow[t]{3}{*}{226.500} & \multirow[t]{3}{*}{0.970} & \multirow[t]{3}{*}{0.985} & \multirow[t]{3}{*}{ ROA } \\
\hline 0.016 & 40.163 & 0.036 & 1.450 & Environmental & & & & & \\
\hline 0.021 & -30.554 & 0.009 & -0.285 & Social & & & & & \\
\hline \multicolumn{5}{|c|}{ Coefficients } & \multirow[t]{2}{*}{ Sig $F^{*}$} & \multirow[b]{2}{*}{$\mathrm{F}$} & \multirow[b]{2}{*}{$\mathrm{R} 2$} & \multirow[b]{2}{*}{$\mathrm{R}$} & \multirow{2}{*}{$\begin{array}{l}\text { dependent } \\
\text { Variables }\end{array}$} \\
\hline Sig t* & $\mathrm{T}$ & Std. Error & $\beta$ & $\begin{array}{l}\text { Independent } \\
\text { Variables }\end{array}$ & & & & & \\
\hline 0.013 & 50.693 & 0.243 & 12.325 & Economic & \multirow[t]{3}{*}{0.018} & \multirow[t]{3}{*}{164.529} & \multirow[t]{3}{*}{0.957} & \multirow[t]{3}{*}{0.978} & \multirow[t]{3}{*}{ ROE } \\
\hline 0.034 & 18.984 & 0.474 & 8.997 & Environmental & & & & & \\
\hline 0.052 & -12.248 & 0.122 & -1.498 & Social & & & & & \\
\hline \multicolumn{5}{|c|}{ Coefficients } & \multirow[t]{2}{*}{ Sig F* } & & & & dependent \\
\hline Sig t* & $\mathrm{T}$ & Std. Error & $\beta$ & $\begin{array}{l}\text { Independent } \\
\text { Variables }\end{array}$ & & $\mathrm{F}$ & $\mathrm{R} 2$ & $\mathrm{R}$ & Variables \\
\hline 0.758 & 0.399 & 0.335 & 0.142 & Economic & 0.483 & 1.864 & 0.762 & 0.873 & LNGAP \\
\hline 0.529 & 0.912 & 0.691 & 0.630 & Environmental & & & & & \\
\hline 0.649 & 0.616 & 0.178 & 0.110 & Social & & & & & \\
\hline Coeffic & & & & & Sig $F^{*}$ & & & & dependent \\
\hline Sig t* & $\mathrm{T}$ & Std. Error & $\beta$ & $\begin{array}{l}\text { Independent } \\
\text { Variables }\end{array}$ & & $\mathrm{F}$ & $\mathrm{R} 2$ & $\mathrm{R}$ & Variables \\
\hline 0.185 & 3.348 & 0.012 & 0.040 & Economic & 0.139 & 27.681 & 0.799 & 0.894 & LOANS/TA \\
\hline 0.184 & 3.368 & 0.023 & 0.079 & Environmental & & & & & \\
\hline 0.073 & 8.665 & 0.006 & 0.052 & Social & & & & & \\
\hline Coeffic & & & & & $\operatorname{Sig} F^{*}$ & & & & dependent \\
\hline Sig t* & $\mathrm{T}$ & Std. Error & $\beta$ & $\begin{array}{l}\text { Independent } \\
\text { Variables }\end{array}$ & & F & $\mathrm{R} 2$ & $\mathrm{R}$ & Variables \\
\hline 0.413 & 1.320 & 0.006 & 0.008 & Economic & 0.676 & 0.721 & 0.684 & 0.827 & INTINCOM \\
\hline 0.591 & 0.748 & 0.011 & 0.008 & Environmental & & & & & $\mathrm{E} / \mathrm{TA}$ \\
\hline 0.594 & 0.741 & 0.003 & 0.002 & Social & & & & & \\
\hline Coeffic & & & & & Sig $F^{*}$ & & & & dependent \\
\hline Sig $t^{*}$ & $\mathrm{~T}$ & Std. Error & $\beta$ & $\begin{array}{l}\text { Independent } \\
\text { Variables }\end{array}$ & & $\mathrm{F}$ & R2 & $\mathrm{R}$ & Variables \\
\hline 0.068 & 1.602 & 0.083 & 0.776 & Economic & 0.111 & 43.135 & 0.822 & 0.907 & WC/TA \\
\hline 0.058 & 1.738 & 0.163 & 1.775 & Environmental & & & & & \\
\hline 0.074 & -0.961 & 0.042 & -0.357 & Social & & & & & \\
\hline Coeffic & & & & & Sig F* & & & & dependent \\
\hline Sig $t^{*}$ & $\mathrm{~T}$ & Std. Error & $\beta$ & $\begin{array}{l}\text { Independent } \\
\text { Variables }\end{array}$ & & $\mathrm{F}$ & R2 & $\mathrm{R}$ & Variables \\
\hline 0.433 & 1.234 & 0.135 & 0.167 & Economic & 0.052 & 99.584 & 0.959 & 0.921 & $\mathrm{OCF} / \mathrm{TA}$ \\
\hline 0.129 & -4.870 & 0.263 & -1.281 & Environmental & & & & & \\
\hline 0.036 & -17.475 & 0.068 & -1.186 & Social & & & & & \\
\hline Coeffic & & & & & Sig $F^{*}$ & & & & dependent \\
\hline Sig t* & $\mathrm{T}$ & Std. Error & $\beta$ & $\begin{array}{l}\text { Independent } \\
\text { Variables }\end{array}$ & & $\mathrm{F}$ & $\mathrm{R} 2$ & $\mathrm{R}$ & Variables \\
\hline 0.630 & 0.658 & 0.035 & 0.023 & Economic & 0.205 & 40.202 & 0.816 & 0.903 & $\mathrm{CR}$ \\
\hline 0.252 & 2.390 & 0.069 & 0.164 & Environmental & & & & & \\
\hline 0.925 & -0.118 & 0.018 & -0.002 & Social & & & & & \\
\hline
\end{tabular}

The results of the table (8) show that: 
1. The results of the above table indicate that the impact of the independent variables (disclosure of the dimensions of the sustainability reporting) on the ROA variable has a statistically significant impact; the calculated $F$ value was $(226.500)$ by ( $\operatorname{Sig} F=0.009$ ), which is less than 0.05 , while the correlation coefficient was $(\mathrm{R}=0.985)$. This indicates that there is a relationship between the independent variables and the dependent variable. Furthermore, the value of the selection coefficient was $(\mathrm{R} 2=0.970)$ which confirms the regression significance. $97.0 \%$ of the variance in the (return on total assets) can be explained by the variation in the (disclosure of the reporting dimensions) in total with all other factors remaining constant. As for the regression coefficients, the value of $\beta$ for the disclosure of the economic aspect was 1.996 and the $\mathrm{T}$ value was $(107.771)$ by a significance of $(\mathrm{Sig}=0.006)$. This confirms the significance of this aspect. Furthermore, the $\beta$ value of the environmental aspect which was (1.450) showed the significant effect of this aspect, where the value of $t$ was $(40.163)$ by $(\mathrm{Sig}=0.016)$, which confirms the significance of this aspect. The $\beta$ value for the disclosure of the social aspect was $(-0.285)$ which showed the negative significant impact of this aspect, where the $\mathrm{T}$ value was $(-30.554)$ by $(\mathrm{Sig}=0.021)$, which confirms the significance of this aspect.

2. The results of the table above indicate that the impact of the independent variables (disclosure of the sustainability reporting dimensions) on the ROE variable is statistically significant where the calculated $\mathrm{F}$ value was (164.529) by (Sig F = 0.018), which is less than 0.05 , while the correlation coefficient was $(\mathrm{R}=0.978)$ which indicates a relationship between the independent variables and the dependent variable. Furthermore, the selection coefficient value was $(\mathrm{R} 2=0.957)$, which shows the correlation of regression. Furthermore, $95.7 \%$ of the variation in the (return on total property rights) can be explained by the variation in the (disclosure of the dimensions of sustainability reports) in total with all other factors remaining constant. As for the regression coefficients, the $\beta$ value of the disclosure of the economic aspect was (12.325) and the T value was (50.693) by ( $\mathrm{Sig}=0.013)$, which confirms the significance of this aspect. However, the $\beta$ value for the disclosure of the environmental aspect was (8.997) which shows the significant impact of this aspect, where the $\mathrm{T}$ value was (18.984) by ( $\mathrm{Sig}=0.034)$, which confirms the significance of this aspect. In addition, the value of $\beta$ for the disclosure of the social aspect was $(-1.498)$ which shows the negative impact of this aspect, where the value of $\mathrm{T}$ was $(-12.248)$ by $(\mathrm{Sig}=0.052)$, which confirms the significance of this aspect.

3. The previous two results are consistent with many accounting theories such as the agency theory, theory of Discrimination, and signal theory, etc., which focus on the relationship among the level of the voluntary disclosures of the organization, its financial performance and its market value. The increase in the level of disclosure increases the confidence of customers such as investors, which reflects on its revenues and level of profitability.

4. The results of the multi-regression analysis have shown that there is no significant impact for the disclosure of the dimensions of sustainability reports combined together on the rest of the continuity indicators. This does not mean that the impact does not exist given the high rates of interpretation in the regression models. The absence of the significant impact 
combined with the high interpretation rates can be explained by the short period of study represented by the years of the issuance of the sustainability reports at the Arab Bank, which began in 2010, and included the disclosure of items for 2009 for comparison purposes. This result is consistent with the previous results, as the prominent significant impact of the disclosure of the aspects of the sustainability reports ( economic, environmental and social) is evident through the bank's mental image, which increases the confidence of customers seeing that the activities of the bank in its pursuit of profits does not conflict with its economic, environmental and social responsibility towards the members of the society and the future generations. This will generally reflect the bank's business results due to the increased customer loyalty and their willingness to deal with it. The lack of a significant impact for all the dimensions can be explained by the short period of the study associated with the date of issuing the sustainability reports by the Arab Bank in 2010. Therefore, we can say though with uncertainty that the lack of the significant impact is due to the nature of disclosures on the aspects of the sustainability reports that take many years to demonstrate the bank's credibility towards achieving a sustainability of the resources for the future generations, and to show its direct impact on all the indicators of continuity.

\section{Conclusion and Recommendations}

\section{Conclusions}

The study is aimed to identify the effect of Accounting Disclosure about sustainability reports ( Social, Environmental, Economic) dimensions on going concern indicators of Arab Bank. Data were collected in the period of 2010-2014. By testing the hypotheses of the study, there is a significant impact of the disclosure of the dimensions of all the sustainability reporting on the (return on assets and the return on equity). This corresponds to the fact that increasing the disclosure rate in general increases the bank's level of confidence, which reflects on the outcome of its work. The lack of an impact on the rest of the sustainability indicators can be attributed to the short study period knowing that the impact of the dimensions of the sustainability accounting might need many years to become tangible.

\section{Recommendations}

Depending on the results, The study recommended the need for Arab Bank to disclose the dimensions of sustainability dimension in accordance to the International disclosure Initiative (GRI, 2014).There is also a need for more disclosure of the accounting activities in annual statements to provide a clearer picture for the sustainability accounting statements and annual statements which reflect the Arab Bank concern with respect to sustain the community resources and its ability to Concern Going.

\section{References}

Allen, L. W. (2006). Why We Need Global Standards for Corporate Disclosure. 69 Law And Contemp. Probs., 167, 175.

Andania, N. P., \& Yadnya, I. P. (2020). The Effect of Sustainability Report Disclosure on Banking Company Financial Performance in Indonesia Stock Exchange. American Journal of 
Humanities and Social Sciences Research, 4(1), 60-67.

Bashatweh, A. D. M. (2018). Accounting Theory and Its Impact on Adoption of Sustainability Reporting Dimensions-A Field Study. International Journal of Accounting and Financial Reporting, 8(4). https://doi.org/10.5296/ijafr.v8i4.13736

Bhuyan, M., Lodh, S. C., \& Perera, N. (2017). The effects of corporate social disclosure on firm performance: empirical evidence from Bangladesh. Accounting and Finance Association of Australia and New Zealand Conference, 1-36. University of Wollongong, Australia.

Bodhanwala, S., \& Bodhanwala, R. (2018). Does corporate sustainability impact firm profitability? Evidence from India. Management Decision, 56(8), 1734-1747.

https://doi.org/10.1108/MD-04-2017-0381

Case, D. W. (2005). Corporate environmental reporting as informational regulation: a law and economics perspective. U. Colo. L. Rev., 76, 379. [Online] Available:

https://ssrn.com/abstract $=1015113$

Darmawan, M. S. (2011). The Relationship between Corporate Social Responsibility and Firm Financial Performance: Evidence from the Firms Listed in LQ45 of the Indonesian Stock Exchange Market. European Journal of Social Sciences, 23(2).

Epstein, M. J., \& Birchard, B. (1999). Counting what counts: Turning corporate accountability to competitive advantage. Perseus Books Group.

Epstein, M. J., \& Roy, M. J. (2001). Sustainability in action: Identifying and measuring the key performance drivers. Long Range Planning, 34(5), 585-604.

https://doi.org/10.1016/S0024-6301(01)00084-X

Erdogan, B. E. (2008). Bankruptcy prediction of Turkish commercial banks using financial ratios. Applied Mathematical Sciences, 2(60), 2973-2982.

Ghazali, N. A. M. (2008). Voluntary disclosure in Malaysian corporate annual reports: views of stakeholders. Social Responsibility Journal, 4, 504-516.

https://doi.org/10.1108/17471110810909902

Global Reporting Initiative (GRI) (2006). Sustainability Reporting Guidelines. version 3.0.

Gujarati, D. N. and Porter, D. C (2004). Basic Econometrics, Ninth Edition, Mc Graw-Hill.

International Accounting Standards, Presentation of Financial Statements (IAS 1).

International Standards on Auditing , ISA, NO.570"Going Concern ".

Kamal, Y., \& Deegan, C. (2013). Corporate Social and Environment-related Governance Disclosure Practices in the Textile and Garment Industry: Evidence from a Developing Country. Australian Accounting Review, 23, 117-134.

https://doi.org/10.1111/j.1835-2561.2012.00205.x

Kasbun, N. F., Teh, B. H., \& San Ong, T. (2017). Sustainability reporting and financial performance of Malaysian public listed companies. Institutions and Economies, 8(4), 78-93. 
https://ijie.um.edu.my/article/view/5052

KPMG International (2008): Sustainability Reporting a guide in Australian.

Leftwich, R. W., Watts, R. L., \& Zimmerman, J. L. (1981). Voluntary corporate disclosure: The case of interim reporting. Journal of accounting research, 19, 50-77. https://doi.org/10.2307/2490984

Ogundele, O. J. K., \& Olajide, O. T. (2012). Inclusive stakeholders approach: basis for acceptable and sustainable industrial relations environment in Nigeria. European Scientific Journal, 8(18).

Oliver's, C. (2011). Measuring Sustainability: A Systems perspective on sustainability reporting frameworks. Master Thesis, Lund University, Sweden.

Pfund, T. (2003). Corporate Environmental Accountability: Expanding SEC Disclosures to Promote Market-Based Environmentalism. Mo. Envtl. L. \& Pol'y Rev., 11, 118. [Online] Available: https://scholarship.law.missouri.edu/jes1/vol11/iss $2 / 2$

Robertson, D. C., \& Nicholson, N. (1996). Expressions of corporate social responsibility in UK firms. Journal of Business Ethics, 15(10), 1095-1106.

https://doi.org/10.1007/BF00412050

Thel, S. (1990). The original conception of section 10 (b) of the Securities Exchange Act. Stanford Law Review, 42(2), 385-464. https://doi.org/10.2307/1228964

Vaziri, M., Bhuyan, R., \& Manuel, P. A. V. (2012). Comparative predictability of failure of financial institutions using multiple models. Investment management and financial innovations, 9(2), 120-127. https://doi.org/10.33107/ijbte.2012.1.1.01

Yongvanich, K., \& Guthrie, J. (2006). An extended performance reporting framework for social and environmental accounting. Business Strategy and the Environment, 15(5), 309-321. https://doi.org/10.1002/bse.541

Zimmerman, J., \& Watts, R. (1986): Positive Accounting theory, Englewood Cliffs, NJ: Prentice Hall.

\section{Copyright Disclaimer}

Copyright for this article is retained by the author(s), with first publication rights granted to the journal.

This is an open-access article distributed under the terms and conditions of the Creative Commons Attribution license (http://creativecommons.org/licenses/by/4.0/). 